\title{
PERAYAAN EKARISTI SEBAGAI SUMBER DAN PUNCAK SELURUH HIDUP KRISTIANI
}

\author{
Don Bosco Karnan Ardijanto \\ STKIP Widya Yuwana \\ modhepr@gmail.com
}

\begin{abstract}
The Eucharist is the source and summit of the Christian life. Many faithful celebrate the Eucharist: some experience the Eucharist's impact, but many do not feel the impact of the Eucharist on their daily lives. The Eucharist is the memory of Christ's sacrifice on the cross. He himself is present at the Eucharist. Therefore the Eucharist is a source of grace and blessing to the lives of the faithful: to bring the fruits of redemption and to be the source of life for the faithful; building-living-reviving the Church. The Eucharist is also a source of repentance and forgiveness as well as a source for developing faith, hope, and love. The Eucharist is the offering of Christ and His Church. Therefore, in the Eucharist the faithful offer their entire lives to be transformed into a source of life and blessing for them and the whole world. In the spirit of repentance, the faithful are also called to offer themselves in faith, hope and love. Celebrating the Eucharist and seriously believing its truths will illuminate the daily lives of the faithful and grow in love for the Eucharist, so that they grow in love for God and others in Christ.
\end{abstract}

Keywords: Eucharist, Christ's sacrifice, dan Christian life.

\section{PENDAHULUAN}

“Gereja hidup dari Ekaristi” (EE 1). Hal ini menegaskan dengan tepat sekali, apa yang telah diajarkan Konsili Vatikan II: "Ekaristi adalah sumber dan puncak seluruh hidup Kristiani” (LG 11) dan “Liturgi (terutama dalam Ekaristi) itu merupakan puncak yang dituju kegiatan Gereja, dan serta merta sumber segala daya kekuatannya” (SC 10). Sedangkan Arah Dasar keuskupan Surabaya menyatakan dengan tegas bahwa Ekaristi adalah sumber dan puncak kehidupan para murid Kristus dan Gereja; tanpa Ekaristi, para murid akan kehilangan kekuatan ilahinya (Keuskupan Surabaya, 2019: 14-15):

Agar dapat senantiasa memiliki kekuatan ilahi dari Kristus Sang Guru sejati, maka ..., Tuhan Yesus telah menyerahkan Tubuh dan Darah-Nya sebagai makanan kehidupan surgawi bagi para muridNya. .... Makanan surgawi inilah yang senantiasa kita terima dalam Ekaristi kudus. Maka tanpa Ekaristi kudus, para murid Kristus akan kehilangan kekuatan Ilahi. Ekaristi adalah sumber dan 
puncak kehidupan murid-murid Kristus yang masih berziarah di dunia ini menuju Kerajaan Bapa. Ekaristi adalah kehidupan bagi Gereja.

Gereja pasti mengharapkan bahwa ajaran "Perayaan Ekaristi adalah sumber dan puncak kehidupannya” itu dapat menjadi keyakinan, pola berpikir dan pola bertindak seluruh umat beriman. Memang harus diakui bahwa di banyak paroki cukup banyak umat beriman dari berbagai kelompok usia, laki-laki dan perempuan dengan rajin mengikuti perayaan Ekaristi setiap hari maupun perayaan Ekaristi Hari Minggu. Dari antara mereka ini ada yang mengalami bahwa hidup kristiani mereka bertumbuh dan berkembang melalui sakramen Ekaristi yang mereka rayakan dengan tekun itu karena Kristus sendiri yang hadir di dalamnya (Brumley, 1996; EE 10). Namun banyak juga dari antara mereka yang tidak mengalami dampak Ekaristi dalam kehidupan mereka sehingga pengaruh perayaan Ekaristi dalam hidup masyarakat juga menjadi kurang tampak (Utama, 2014: 75; EE 10).

Hal ini menimbulkan suatu pertanyaan: bagaimana membantu umat beriman memahami ajaran ini sehingga mampu mewujudkan ajaran itu di dalam hidup mereka sehari-hari? Diharapkan melalui uraian berikut ini umat beriman mampu memahami makna ajaran perayaan Ekaristi sebagai sumber dan puncak kehidupan kristiani dan mampu mewujudkannya dalam hidup mereka sehari-hari.

\section{EKARISTI SEBAGAI SUMBER DAN PUNCAK KEHIDUPAN KRISTIANI}

... Liturgi itu puncak yang dituju kegiatan Gereja, dan serta merta sumber segala daya-kekuatannya. ....

... Liturgi sendiri mendorong Umat beriman, supaya sesudah dipuaskan "dengan Sakramen-sakramen Paska menjadi sehatisejiwa dalam kasih". Liturgi berdoa supaya "mereka mengamalkan dalam hidup sehari-hari apa yang mereka peroleh dalam iman”. ... Ekaristi menarik dan mengobarkan Umat beriman dalam cinta kasih Kristus yang membara. Jadi dari Liturgi, terutama dari Ekaristi, bagaikan dari sumber, mengalirlah rahmat kepada kita, dan dengan hasil guna yang amat besar diperoleh pengudusan manusia dan permuliaan Allah dalam Kristus, tujuan semua karya Gereja lainnya (SC 10).

Ajaran Ekaristi sebagai sumber dan puncak seluruh hidup Kristiani menunjukkan bahwa Gereja melihat Ekaristi dan kehidupan sehari-hari umat Kristiani sebagai satu kesatuan yang tidak terpisahkan. Perayaan Ekaristi memiliki hubungan dialogis-mutual dan tak terpisahkan dengan kehidupan sehari-hari orang Kristen. Ekaristi menjadi sumber daya dan kekuatan yang menggerakkan dan menghidupi hidup sehari-hari orang kristen sekaligus perayaan Ekaristi 
menjadi arah dan tujuan setiap kegiatan hidup harian umat beriman (Martasudjito, 2003: 297).

Selain itu Gereja juga menyatakan bahwa perayaan Ekaristi merupakan peristiwa perjumpaan dialogis-mutual yang menyelamatkan antara Allah dengan manusia: suatu tindakan saling memberi dan saling menerima, suatu perjanjian cintakasih yang terjadi dalam-melalui-bersama Kristus. Dalam Ekaristi serentak Allah menyelamatkan dan menguduskan umat manusia, sedangkan manusia menjawab dan menanggapi dalam iman dengan syukur dan pujian (Brumley, 1996):

As the source of Christian spirituality, the Eucharist revealed that our salvation begins with, not ourselves. God offers Himself to man in Christ first. At the same time, as the summit of Christian spirituality, the Eucharist is man's supreme, grace- enabled, freely given offering of himself back to God through Jesus Christ, our high priest, by the power of the Holy Spirit. The union or intimate, personal fellowship between God and man realized through God's gift of Himself to man and man's faithful response, we call.

\section{EKARISTI SEBAGAI SUMBER KEHIDUPAN KRISTIANI}

Sebagai sumber hidup Kristiani, Ekaristi merupakan sumber rahmat dan sumber pertumbuhan iman, harapan, dan kasih bagi setiap orang Kristiani (CBCR, 2006).

\subsection{Ekaristi sebagai Sumber Rahmat}

Ekaristi menjadi sumber rahmat bagi hidup kristiani dalam berbagai cara:

Pertama, Ekaristi adalah Kristus sendiri-Sumber Kehidupan umat manusia: "Dalam Ekaristi suci tercakuplah seluruh kekayaan rohani Gereja, yakni Kristus sendiri, Paskah kita dan Roti hidup, ... menjadi sumber kehidupan mengaruniakan kehidupan kepada manusia” (PO 5; KGK 1324). "Dia hadir dalam sakramen-sakramen-Nya, ..., dalam kurban misa, dan dalam pribadi orang yang melaksanakan pelayanan imami, tetapi Ia hadir ... terutama dalam kedua rupa Ekaristi” (SC 7).

Kedua, Ekaristi merupakan Kurban Kristus di salib yang dilaksanakan secara sakramental. Ekaristi menghadirkan dan mengaktualkan kembali Kurban Salib Kristus yang terjadi sekali untuk selama-lamanya secara sakramental (KGK 1362-1367):

Kurban Kristus dan kurban Ekaristi hanya satu kurban: "karena bahan persembahan adalah satu dan sama; yang sama, yang dulu mengurbankan diri di salib, sekarang membawakan kurban oleh pelayanan imam; hanya cara berkurban yang berbeda". "Dalam kurban ilahi ini, yang dilaksanakan di dalam misa, Kristus yang sama itu hadir dan dikurbankan secara tidak berdarah... yang mengurbankan diri sendiri di kayu salib secara berdarah satu kali untuk selama-lamanya" (Konsili Trente: DS 1743). 
Sebagai kenangan akan kurban salib, Ekaristi menganugerahkan buahbuahnya, yakni penebusan umat manusia: "Setiap kali di altar dirayakan korban salib, tempat Anak Domba Paska kita, yakni Kristus, telah dikorbankan, dilaksanakanlah karya penebusan kita” (LG 3) dan pengampunan dosa yang dilakukan manusia setiap hari (KGK 1366):

Kristus "memang hendak mengurbankan diri kepada Allah Bapa, satu kali untuk selama-lamanya di altar salib melalui kematian yang datang menjemputNya (Ibr 7: 27), untuk memperoleh penebusan abadi bagi mereka [manusia]; tetapi karena imamatNya tidak dihapuskan oleh kematian-Nya (Ibr 7: 24), maka dalam perjamuan malam terakhir, 'pada malam waktu Ia diserahkan' (1 Kor 11: 23), Ia meninggalkan bagi mempelai kekasih-Nya, Gereja, satu kurban yang kelihatan (seperti yang dibutuhkan kodrat manusia), yang olehnya, [kurban] berdarah itu, yang dibawakan di salib satu kali untuk selama-lamanya, dikenang sampai akhir zaman dan kekuatannya yang menyelamatkan dipergunakan untuk pengampunan dosa, yang kita lakukan setiap hari" (Konsili Trente: DS 1740).

Ketiga, Ekaristi juga merupakan kurban Gereja. Dalam kesatuan dengan kurban Kristus-Sang Kepala Tubuh, Gereja juga mempersembahkan diri kepada Bapa untuk keselamatan semua manusia (KGK 1368). Di dalam Ekaristi, persembahan diri Kristus juga menjadi persembahan diri Gereja, anggota-anggota tubuh-Nya (Doa Syukur Agung 3): yang masih hidup (KGK 1369), yang mulia di surga (KGK 1370), yang sudah meninggal-belum disucikan seluruhnya (KGK 1371). Di dalam Ekaristi hidup harian umat beriman—-kegembiraan dan harapan, duka dan kecemasan, doa dan karya atau usaha - dipersatukan dengan kurban dan penyerahan diri Kristus seutuhnya, sehingga menemukan makna baru yang mendatangkan rahmat kehidupan dan keselamatan bagi umat beriman. Dengan cara ini, Gereja dibangun di dalam anggota-anggotanya sebagai tubuh Kristus dan bait Roh Kudus. Dengan demikian, Ekaristi menjadi sumber rahmat yang “membangun Gereja” (KGK 1396), menghidupi dan menghidupkan Gereja (EE 1, 21-24).

Keempat, Ekaristi merupakan sumber pertobatan dan pengampunan dosa. Di dalam Perayaan Ekaristi terdapat bagian-bagian yang dengan gamblang mengajak umat beriman untuk memeriksa diri, menyesali dan mengakui diri sebagai orang berdosa agar bertobat sehingga layak dan pantas ikut serta di dalamnya: 1) pernyataan tobat, 2) seruan Tuhan kasihanilah kami, 3) doa sebelum komuni: "Ya Tuhan, saya tidak pantas...", dan terutama 4) dalam Doa Syukur Agung: "Terimalah dan minumlah, inilah piala darahku, darah perjanjian baru dan kekal, yang ditumpahkan bagimu dan bagi semua orang demi pengampunan dosa” (Martasudjita, 2018: 24-26). 
Selain itu, Gereja juga mengajarkan dengan tegas bahwa penerimaan Ekaristi Kudus yang berbuah dan penuh hormat mengharuskan seseorang untuk memeriksa dirinya secara rohani sebelum datang ke perjamuan Ekaristi dan, jika dia sadar akan dosa besar, maka dia wajib menerima sakramen rekonsiliasi sebelum menerima Kristus dalam Komuni Kudus (KHK 916; KGK 1415; RS 81). Ekaristi juga mengundang umat beriman untuk merenungkan Kurban Kristus yang hadir dalam Ekaristi demi penghapusan dosa-dosa manusia dan mendorong mereka untuk melakukan pertobatan terus menerus.

\subsection{Ekaristi sebagai Sumber Iman, Harapan, dan Kasih}

Ekaristi juga dapat menjadi sumber rahmat yang menumbuhkan dan memperkokoh keutamaan-keutamaan teologal (iman, harapan, dan kasih) dalam diri umat beriman. Ketiga keutamaan ini memungkinkan umat beriman hidup dalam persekutuan dengan Allah Tritunggal dan mengambil bagian dalam kodrat ilahi-Nya (KGK 1812).

\subsubsection{Ekaristi sebagai Sumber Iman}

Seperti semua sakramen (KGK 1123), Ekaristi adalah tanda yang mendidik, memupuk, meneguhkan dan mengungkapkan iman melalui apa yang ditandakan. Dalam Sakramen Ekaristi, kehadiran Kurban Salib Kristus dan kehadiran Kristus secara real merupakan tanda atau sakramen yang menyatakan hikmat, kasih, dan kuasa Allah bagi manusia dalam Kristus sebagai yang ditandakan. Dalam arti ini, Ekaristi dapat disebut sebagai tanda perjanjian sakramental yang memasukkan manusia ke dalam persekutuan dengan Allah karena ia mengimani karya penyelamatan Allah, yang memuncak dalam wafat dan kebangkitan Putra-Nya. Dengan merayakan Ekaristi terus menerus, umat beriman didorong untuk semakin percaya akan karya penyelamatan Allah yang dinyatakan dalam Kristus, yakni penebusan umat manusia.

Selain itu, sakramen Ekaristi juga mampu menumbuhkan keutamaan iman, karena perayaan Ekaristi itu mengungkapkan kesatuan iman Gereja Katolik. Secara nyata iman akan karya penebusan Kristus yang dihadirkan dan diaktualkan kembali di dalam perayaan Ekaristi, didasarkan pada pewartaan Sabda Allah dalam liturgi Ekaristi dan dirayakan dalam Kurban Ekaristi yang dipimpin oleh klerus dalam persekutuan dengan uskup dan para pengganti Petrus yang sah.

\subsubsection{Ekaristi sebagai Sumber Harapan}

Harapan Kristiani adalah mengalami kehidupan dan kebahagiaan abadi di kerajaan surga bersama Allah Tritunggal dan para kudus-Nya berkat misteri Paskah Kristus dan bantuan rahmat Roh Kudus, jadi tidak bersandar pada kekuatan manusia sendiri (KGK 1817). Dasar dari harapan ini adalah misteri 
Paskah Kristus dan karunia Roh Kudus-Nya yang dicurahkan di dalam hati kita (Roma 5: 5-11; 8: 23-25; Titus 3: 6-7), yang secara sakramental hadir dalam Ekaristi.

Sebagai kenangan akan misteri Paskah Kristus, perayaan Ekaristi menghidupkan harapan, bahkan jaminan paling aman umat beriman akan persekutuan dengan Allah dalam hidup di dunia ini dan untuk mewarisi kehidupan kekal di surga (KGK 1405). Karena itu, dengan merayakan Ekaristi umat beriman memelihara harapan untuk mengalami karya penyelamatan Allah dalam Kristus sekaligus mengharapkan kedatangan kerajaan Allah (kedatangan-Nya kita rindukan) dan kehidupan kekal dalam persekutuan dengan Allah Tritunggal.

Dalam Liturgi di dunia ini kita ikut mencicipi Liturgi surgawi, yang dirayakan di kota suci Yerusalem, tujuan peziarahan kita. Di sana Kristus duduk di sisi kanan Allah, sebagai pelayan tempat tersuci dan kemah yang sejati. Bersama dengan segenap bala tentara sorgawi kita melambungkan kidung kemuliaan kepada Tuhan. Sementara menghormati dan mengenangkan para kudus kita berharap akan ikut serta dalam persekutuan dengan mereka. Kita mendambakan Tuhan kita Yesus Kristus penyelamat kita, sampai Ia sendiri, hidup kita, akan nampak, dan kita akan nampak bersama dengan-Nya dalam kemuliaan (SC 8).

\subsubsection{Ekaristi sebagai Sumber Kasih}

Sebagai kenangan akan wafat dan kebangkitan Kristus, Ekaristi juga disebut sebagai sakramen cinta kasih (KGK 1323). Ekaristi secara sakramental merupakan tanda perwujudan kasih Allah yang menyelamatkan umat manusia sekaligus Kristus sendiri, kasih yang menjelma. Ekaristi merupakan sumber kasih yang dapat menuntun umat beriman untuk mengasihi Allah dan Yesus dalam Roh Kudus. Dengan merayakan Ekaristi umat beriman di satu pihak mengalami kasih Allah yang menyelamatkan dalam Kristus yang hadir dalam Ekaristi, di lain pihak juga dipanggil untuk menanggapi kasih Allah itu dengan semakin mendalam mengasihi Allah dan sesama.

Melalui Ekaristi, seseorang mampu semakin berpartisipasi dalam kehidupan Allah Tritunggal, yang adalah cinta kasih itu sendiri (1Yoh 4: 16). Dan pada saatnya, persekutuan kasih yang mendalam dengan Allah ini mendesak dan mengarahkan seseorang untuk mencintai sesama sebagai wujud kasih kepada Allah, karena "barangsiapa mengasihi Allah, dia harus juga mengasihi saudaranya" (1Yoh 4: 21). Dengan kata lain, kasih kepada sesama bersumber dari pengalaman dicintai Allah dalam Kristus. Dengan demikian, Ekaristi dapat menjadi sekolah cinta kasih. Dalam dan melalui Ekaristi seseorang dapat belajar dari Kristus bagaimana mengasihi Allah dan sesama secara utuh dan penuh, sekaligus dapat menimba daya kekuatan kasih sejati yang berasal dari Kristus 
sendiri sehingga seseorang mampu mengasihi Allah dan sesama seperti kasih Kristus itu sendiri.

Akhirnya, sebagai sumber kasih, Ekaristi memampukan seseorang-pada saat diperlukan-memiliki ketaatan sejati kepada perintah-perintah Allah: "inilah kasih kepada Allah, yaitu, bahwa kita menuruti perintah-perintah-Nya" (1Yoh 5: 3); tanpa kasih semacam ini seseorang tidak dapat sungguh-sungguh mencintai Tuhan.

\section{EKARISTI SEBAGAI PUNCAK KEHIDUPAN KRISTIANI}

Ekaristi adalah puncak kehidupan Kristiani dalam arti bahwa seluruh aspek kehidupan Kristen diarahkan dan ditujukan kepada Ekaristi, dimana dalam Ekaristi Kristus mempersembahkan diri-Nya kepada Bapa dalam Roh Kudus bagi keselamatan manusia sekaligus seluruh kehidupan umat beriman dipersatukan di dalam kurban Kristus sendiri. Tampak di sini adanya hubungan sakramental yang sama antara kurban salib dan Ekaristi yang menjadikan Ekaristi sebagai sumber hidup Kristiani sekaligus sebagai puncak hidup Kristiani.

\subsection{Kurban Kristus, Kurban Kita}

Dalam Ekaristi, Kristus mempersembahkan diri-Nya kepada Bapa bagi kita sekaligus Kristus juga dipersembahkan Gereja kepada Bapa melalui Roh Kudus lewat pelayanan imam yang bertindak in persona Christi dan dalam kesatuannya dengan Kristus sebagai anggota Gereja. Bukan hanya Kristus saja yang mempersembahkan diri-Nya, melainkan Gereja juga mempersembahkan dirinya dalam kesatuan dengan Kristus dalam Roh Kudus.

Bapa, kami mengenangkan sengsara Putra-Mu yang menyelamatkan, kebangkitan-Nya yang mengagumkan, dan kenaikan-Nya ke surga. ..., dengan penuh syukur kami mempersembahkan kepada-Mu kurban yang hidup dan kudus ini. Kami mohon, pandanglah persembahan Gereja-Mu ini dan indahkanlah kurban yang telah mendamaikan kami dengan Dikau ini. ... Semoga kami disempurnakan oleh-Nya menjadi suatu persembahan abadi bagi-Mu .... (Doa Syukur Agung 3)

Dalam Ekaristi, kurban Kristus juga menjadi kurban Gereja, anggota tubuh-Nya. Kehidupan umat beriman (kegembiraan dan harapan, duka dan kecemasan, doa dan pekerjaan) diarahkan dan dipersatukan dengan hidup dan kurban Kristus berkat kuasa Roh Kudus dan sabda Tuhan Yesus sendiri memperoleh makna baru (KGK 1368) dan diubah menjadi sumber hidup dan sumber berkat bagi umat beriman dan dunia. Dari pihak umat beriman dituntut kesediaan diri (niat dan tindakan) untuk mempersembahkan dan mempersatukan diri (pikiran, hati, dan hidup harian mereka) dengan kurban Kristus di altar 
sehingga kurban Kristus berdaya guna menghadirkan keselamatan bagi mereka sendiri maupun dunia.

Sebagai puncak hidup Kristiani yang mendatangkan rahmat penebusan dan pertumbuhan hidup Kristiani, Ekaristi juga menuntut umat beriman untuk selalu bertobat dan kesediaan diri untuk berkurban.

\subsection{Panggilan untuk Bertobat}

Ekaristi adalah puncak (arah dan tujuan) hidup Kristiani, termasuk juga pertobatan dari dosa. Dalam Ekaristi umat beriman datang kepada Allah membawa beban dosa dan berdoa: "Saya mengaku kepada Allah yang mahakuasa ...,” dan "Tuhan, kasihanilah kami.” Umat beriman telah berdosa tidak hanya kepada Allah, tetapi juga kepada sesamanya sehingga mereka memohon kepada saudara-saudari sekalian "supaya mendoakan ... pada Allah, Tuhan kita” (FABC, 2009: 9). Ekaristi dan pertobatan adalah dua hal yang tak terpisahkan. Kalau seseorang hendak mempersembahkan diri kepada Allah melalui Ekaristi dan hendak bersatu dengan Kristus, sang Roti Hidup, maka dia harus menjalani pemurnian diri dan mohon pengampunan dosa (KHK 916; KGK 1415; RS 81). Paus Pius XII—sebagaimana dikutip Brumley (1996)—mengatakan:

Sementara kita berdiri di depan altar ... adalah tugas kita untuk mengubah hati kita bahwa setiap jejak dosa dapat dihapuskan sepenuhnya, sementara apa pun yang menumbuhkan kehidupan adikodrati melalui Kristus, dapat dengan penuh semangat dibina dan diperkuat bahkan sejauh, dalam persatuan dengan Korban yang Tak Bernoda, kita menjadi korban yang dapat diterima oleh Bapa yang Kekal.

Bertolak dari pewartaan Yesus yang menghubungkan pertobatan dan iman: "Bertobatlah dan percayalah kepada Injil” (Mrk 1: 15), Yohanes Paulus II—sebagaimana dikutip Brumley (1996)—dengan tegas menunjukkan hubungan antara sakramen tobat dan sakramen Ekaristi:

Ekaristi dan Tobat merupakan dua hal yang saling berhubungan erat seperti halnya hidup seturut semangat Injil dan hidup Kristen yang sejati. Sebab Kristus yang mengundang umat beriman ke perjamuan Ekaristi adalah sama dengan Kristus yang memanggil umat beriman untuk bertobat terus menerus. Tanpa upaya konstan untuk pertobatan terus menerus semacam ini, maka mengambil bagian dalam Ekaristi tidak akan sepenuhnya efektif menebus dosa, malahan akan menghilangkan atau setidaknya melemahnya kesiapsediaan umat beriman secara khusus untuk mempersembahkan kepada Tuhan kurban rohani di mana di dalam Ekaristi umat beriman ambil bagian dalam imamat Kristus dalam cara yang esensial dan universal. 
Karena itu, Ekaristi haruslah menjadi puncak pertobatan umat beriman karena Ekaristi adalah puncak kehadiran Misteri Paskah, sumber penebusan dan pengampunan dosa manusia. Semua tindakan-tindakan pertobatan dari dosa lainnya mempersiapkan partisipasi kita dalam Kurban Ekaristi, sehingga Ekaristi menjadi saat terpenting untuk menolak dosa dan berbalik kepada Kristus dan Bersatu mesra dengan-Nya.

\subsection{Mempersembahkan Diri dalam Iman, Harapan, dan Kasih}

Kehidupan Kristiani tidak hanya sekedar perjuangan untuk bertobat dan memurnikan diri, melainkan juga usaha untuk menumbuhkan dan mengembangkan iman, harapan, dan kasih. Karena itu, kurban persembahan hidup Kristiani dalam Ekaristi juga harus menumbuhkan keutamaan-keutamaan teologal dalam diri umat beriman.

Iman adalah penyerahan diri pribadi, jawaban manusia terhadap inisiatif Allah menyelamatkan manusia dalam Kristus, di mana seseorang secara bebas menyerahkan akal budi dan kehendaknya kepada Allah dan firman-Nya (KGK 143, 1814). Dalam Ekaristi, manusia mengungkapkan ketaatan imannya kepada Sabda ilahi yang mengubah roti dan anggur menjadi Tubuh dan Darah Kristus (KGK 1375-1376) dan kepada seluruh Iman Katolik yang mengajarkan bahwa Ekaristi adalah tanda sakramental terbesar, yakni: Kristus sendiri. Karena itu, Ekaristi disebut sebagai Misteri Iman.

Pada saat menerima Komuni Suci, dalam iman orang beriman memberi hormat di depan misteri ini dan menerima kebenarannya: "jikalau kamu tidak makan daging Anak Manusia dan minum darah-Nya, kamu tidak mempunyai hidup di dalam dirimu. ... Sebab daging-Ku adalah benar-benar makanan dan darah-Ku adalah benar-benar minuman” (Yoh 6: 53, 55). Dan dalam iman seseorang menyerahkan dirinya kepada Kristus dan menjawab: "Ya Tuhan, aku percaya akan Sabda-Mu karena Sabda-Mu adalah Sabda hidup kekal” (Yoh 6: 68).

Santo Thomas Aquinas mengungkapkan ketaatan iman itu di dalam himne Adoro Te Devote:

Aku sembah sujud di hadapan-Mu. Tuhan yang tersamar hadir di sini. Hanya rupa roti tertampak kini. Namun aku yakin akan Sabda-Mu.

Pancainderaku tak menangkapnya. Namun aku yakin akan SabdaMu. Sebab hanya Sabda Allah Putera. Kebenaran mutlak tak tersangkalkan. (KGK 1381)

Tindakan iman yang paling agung dari umat beriman terwujud secara istimewa pada saat dia percaya dan yakin akan karya penyelamatan Allah dalam wafat dan kebangkitan Kristus demi penebusan umat manusia. Dalam Ekaristi, 
tindakan penyelamatan Allah dalam Kristus itu hadir dan dinyatakan. Karena itu, Ekaristi sungguh menuntut ketaatan iman penuh: persembahan diri dalam iman.

Selanjutnya, persembahan diri umat beriman dalam Ekaristi berarti juga meletakkan harapan dan percaya pada rahmat Tuhan yang dijanjikan dalam Ekaristi dan bahwa "Dia, yang memulai pekerjaan yang baik ... akan meneruskannya sampai pada akhirnya pada hari Kristus Yesus” (Flp 1: 6). Di dalam harapan, umat beriman mengakui kelimpahan Allah sekaligus keterbatasan dirinya sendiri. Mempersembahkan diri kepada Allah dalam Ekaristi adalah tindakan pengharapan yang mendalam karena Ekaristi adalah Kristus sendiri yang dikurbankan demi pengampunan dosa manusia. Memang hanya dalam Kristus, melalui Kristus, dan bersama Kristus imam dan kurban yang hadir dalam Ekaristi, umat beriman dapat berharap bahwa persembahan dirinya akan diterima oleh Allah Bapa. Kurban Ekaristi menjadi cara teragung untuk mengungkapkan harapan kita kepada Allah.

Dengan demikian, bersatu dengan Kristus dalam Ekaristi berarti mengakui keterbatasan/kedosaan dan menaruh harapan pada kemurahan Allah untuk membawa umat manusia kepada kehidupan kekal bersamanya. Ekaristi adalah “janji kemuliaan yang akan datang” (KGK 1402) dan “jaminan yang paling aman dan tanda yang paling jelas bahwa harapan besar akan surga baru dan dunia baru, di mana terdapat keadilan akan terpenuhi” (KGK 1405). Karena itu, merayakan Ekaristi berarti mempersembahkan pengharapan kepada Allah supaya Allah mencurahkan rahmat yang sangat diperlukan oleh umat beriman untuk setia di sini dan saat ini, serta untuk mencapai hidup kekal bersama Dia dalam kemuliaan.

Ekaristi adalah sakramen cinta bagi umat beriman sekaligus bagi Allah dan umat manusia. Melalui kasih, manusia memeluk Allah yang adalah kasih. Dengan mempersembahkan diri dan bersatu dengan Allah dalam Ekaristi, kasih manusia kepada Allah mencapai puncaknya, yakni: dengan memberikan diri kepada Allah dalam-melalui-bersama Kristus sendiri. Dengan cara ini, tawaran Allah untuk bersatu dengan manusia dijawab melalui persatuan kasih dengan Kristus dalam Ekaristi.

"Tidak ada kasih yang lebih besar dari pada kasih seorang yang memberikan nyawanya untuk sahabat-sahabatnya” (Yoh 15: 13). Tindakan kasih Kristus ini diwujudkan di dalam kurban salib yang hadir dalam Ekaristi. Di dalam dan melalui Ekaristi, umat beriman menyatukan dirinya dengan Kristus dan menyerahkan hidupnya dalam persatuan penuh kasih dengan tindakan ketaatan Yesus kepada kehendak Bapa. Seperti Kristus taat kepada kehendak Bapa-Nya: "bukanlah kehendak-Ku, melainkan kehendak-Mulah yang terjadi” (Luk 22: 42), demikian pula umat beriman menyatukan hidupnya dengan Kristus dalam Ekaristi sambil berdoa kepada Bapa: “terjadilah kehendak-Mu.” Seperti ketaatan Yesus sampai mati merupakan ungkapan cinta-Nya kepada Bapa dan umat manusia, 
demikian pula di dalam Ekaristi umat beriman mengambil bagian di dalam cinta Kristus kepada Bapa dengan menyerahkan diri dan menyerahkan seluruh kehendak mereka kepada kehendak Allah melalui Yesus sampai kematian menyatukan mereka dengan Kristus.

Ekaristi tidak hanya mengungkapkan kasih kepada Allah saja, melainkan juga menyatakan dan mewujudkan kasih kepada sesama. Memasrahkan kehendak sepenuhnya kepada Allah dalam kasih berarti ingin selalu melaksanakan kehendak Allah, yakni: "kasihilah sesamamu manusia seperti dirimu sendiri” (Luk 10: 27). Karena itu, dalam Ekaristi kurban diri umat beriman mencakup juga mengasihi dan melayani sesama karena "Barangsiapa mengasihi Allah, ia harus juga mengasihi saudaranya” (1Yoh 4: 21).

Salah satu wujud cinta kepada sesama adalah berdoa kepada Bapa bagi keselamatan mereka sendiri dan bagi umat manusia, baik yang berada dalam kesatuan dengan Gereja maupun yang tidak, juga bagi mereka yang masih hidup maupun yang sudah meninggal. Tugas imamat umat beriman diungkapkan dan diwujudkan secara istimewa dalam Ekaristi karena Ekaristi merupakan doa terluhur yang dapat mempersembahkan dan menghadirkan Kurban Kristus sehingga segala bentuk doa lainnya menjadi berdaya guna.

Oleh karena itu, Ekaristi adalah sakramen yang menyatukan seluruh anggota Tubuh Kristus dalam iman, harapan, dan kasih. Dalam Ekaristi umat beriman dipersatukan oleh iman, harapan, dan kasih. Dan melalui Ekaristi umat beriman dipersatukan dalam iman, harapan, dan kasih dengan sesamanya.

... Liturgi itu puncak yang dituju kegiatan Gereja, ... supaya semua orang ... menjadi putera-putera Allah, berhimpun menjadi satu, meluhurkan Allah ditengah Gereja, ikut serta dalam Korban dan menyantap perjamuan Tuhan.

Dilain pihak Liturgi sendiri mendorong Umat beriman, supaya ... menjadi sehati-sejiwa dalam kasih. ... mengamalkan dalam hidup sehari-hari apa yang mereka peroleh dalam iman ... menarik dan mengobarkan Umat beriman dalam cinta kasih Kristus yang membara.

Jadi dari Liturgi, terutama dari Ekaristi, bagaikan dari sumber, mengalirlah rahmat kepada kita, dan dengan hasil guna yang amat besar diperoleh pengudusan manusia dan permuliaan Allah dalam Kristus, tujuan semua karya Gereja lainnya (SC 10).

Dengan cara demikian, seluruh umat beriman dipersatukan menjadi satu tubuh, satu roh dalam Kristus: mengambil bagian dalam liturgi surgawi secara kurang sempurna di dunia ini dan dalam persatuan dengan Allah yang menjadi arah dan tujuan hidup Kristiani. Dengan demikian, Ekaristi di dunia ini adalah antisipasi perjamuan eskatologis Anak Domba, saat Kristus dan Gereja-Nya mengalami persatuan sempurna. 


\section{KESIMPULAN}

Ekaristi adalah sumber dan puncak seluruh hidup kristiani. Ekaristi adalah sumber seluruh hidup Kristiani karena Ekaristi adalah Kristus sendiri. Dalam Ekaristi kurban salib Kristus hadir secara sakramental bagi keselamatan umat manusia. Sebagai anggota Gereja, umat beriman menerima rahmat demi rahmat dari Ekaristi untuk bertumbuh dalam persatuan dengan Allah: berbalik dari dosa dan semakin kokoh dalam iman, harapan, dan kasih.

Ekaristi juga adalah puncak seluruh hidup Kristiani karena di dalam Ekaristi umat beriman mengambil bagian dalam kurban diri Kristus secara sakramental kepada Bapa dalam kekuatan Roh Kudus, baik secara komunal maupun secara pribadi. Dalam Ekaristi, sebagai anggota Gereja, tubuh Kristus umat beriman secara pribadi mempersembahkan diri, mati bagi diri sendiri dan bertobat dari dosa, serta persembahan itu disempurnakan melalui penyerahan diri kepada Allah dalam iman, harapan, dan kasih yang mempersatukan kita dalam kurban Kristus sendiri.

Merenungkan dan mengimani secara sungguh kebenaran-kebenaran tentang Ekaristi dalam kehidupan umat beriman akan menerangi hidup beriman mereka dan memberi lebih banyak alasan untuk semakin mencintai Ekaristi, sehingga semakin membantu mereka untuk tumbuh lebih akrab dengan Allah dan dengan sesama dalam Kristus. Dengan demikian umat beriman akan mengenal secara lebih dalam lagi bahwa dalam dan melalui Ekaristi umat manusia menerima anugerah pemberian dari diri Bapa di dalam Putra-Nya, sekaligus dalam dan melalui Ekaristi umat beriman memberikan jawaban penuh cinta: menyatukan diri dalam penyerahan diri Putra kepada Bapa. 


\section{DAFTAR PUSTAKA}

Brumley, Mark. 1996. The Eucharist: Source and Summit of Christian Spirituality. Diambil dari https://www.ewtn.com/catholicism/library/ eucharist-source-and-summit-of-christian-spirituality-10380. Diakses pada 10 November 2019. Pk. 21.30.

Chinese Regional Bishops' Conference (CBCR). 2006. The Sacrament of the Holy Eucharist is the Source and Summit of the Life and Mission of the Parish and Church Organizations diambil dari https://www.catholic.org.tw/en/ Document/documentsummit.htm. Diakses pada 10 November 2019. Pk. 22.00

Federation of Asian Bishops' Conferences. 2010. Living the Eucharist in Asia: Final Document of the 9th FABC Plenary Assembly. Diambil dari www. fabc.org/.../FABC\%20IX\%20PA\%20Final\%20Document.pdf.

Diakses pada 22 November 2019. Pk. 19.15.

Keuskupan Surabaya. 2019. Seri Mupas 2019, Buku 1: Arah Dasar Keuskupan Surabaya Tahun 2020 - 2030. Surabaya: Pengarang.

Kongregasi Ibadat dan Tata-tertib Sakramen. 2004. Redemptoris Sacramentum (Sakramen Penebusan - terjemahan). Jakarta: Obor.

Konsili Vatikan II, 2004. Dokumen Konsili Vatikan II (Terjemahan $R$. Hardawiryana). Jakarta: Obor.

Martasudjita, Emanuel. 2003. Ekaristi: Tinjauan Teologis, Liturgis, dan Pastoral. Yogyakarta: Kanisius.

Martasudjita, Emanuel. 2018. Makna Ekaristi: Kehadiran Tuhan dalam Hidup Sehari-hari. Yogyakarta: Kanisius.

N.N. 1995. Katekismus Gereja Katolik (terjemahan P. Herman Embuiru). Ende: Arnoldus.

N.N. 2010. Kitab Hukum Kanonik (terjemahan). Jakarta: Obor.

Paulus II, Yohanes. 2003. Ecclesia de Eucharistia (Ekaristi dan Hubungannya dengan Gereja - terjemahan). Jakarta: Departemen Dokumentasi dan Penerangan KWI.

Utama, Ignatius Loyola Madya. Mei 2014. Menjadikan Ekaristi Sebagai Puncak dan Sumber Kehidupan Gereja dalam Jurnal Teologi, Vol. 03, No. 01. Mei 2014, hlm. 75-81 diambil dari https://e-journal.usd.ac.id/index.php/jt/ article/download/453/394. Diakses pada 8 November 2019 pk. 18.10. 